Reflections on Translation 


\section{TOPICS IN TRANSLATION}

Series Editors: Susan Bassnett, University of Warwick, UK and Edwin Gentzler, University of Massachusetts/Amherst, USA

Work in the field of Translation Studies has been expanding steadily over the last two decades, not only in linguistics and literacy studies, but also in business studies, economics, international studies, law and commerce. Translation Studies as a discipline in its own right has developed alongside the practice of teaching and training translators. The editors of the Topics in Translation series encourage research that spans the range of current work involving translators and translation, from the theoretical to the practical, from computer assisted translation to the translation of poetry, from applied translation to the history of translation.

Full details of all the books in this series and of all our other publications can be found on http:/ / www.multilingual-matters.com, or by writing to Multilingual Matters, St Nicholas House, 31-34 High Street, Bristol BS1 2AW, UK. 


\title{
TOPICS IN TRANSLATION
}

Series Editors: Susan Bassnett, University of Warwick, UK and

Edwin Gentzler, University of Massachusetts/Amherst, USA

\section{Reflections on Translation}

\author{
Susan Bassnett
}

\section{MULTILINGUAL MATTERS}

Bristol • Buffalo • Toronto 


\section{To my brother Steve, another kind of translator}

\section{Library of Congress Cataloging in Publication Data}

A catalog record for this book is available from the Library of Congress.

Bassnett, Susan.

Reflections on Translation/Susan Bassnett.

Topics in Translation: 39

Includes bibliographical references and index.

1. Translating and interpreting. I. Title.

P306.B295 2011

418'.02-dc22 2011015598

\section{British Library Cataloguing in Publication Data}

A catalogue entry for this book is available from the British Library.

ISBN-13: 978-1-84769-409-6 (hbk)

ISBN-13: 978-1-84769-408-9 (pbk)

\section{Multilingual Matters}

UK: St Nicholas House, 31-34 High Street, Bristol, BS1 2AW, UK.

USA: UTP, 2250 Military Road, Tonawanda, NY 14150, USA.

Canada: UTP, 5201 Dufferin Street, North York, Ontario, M3H 5T8, Canada.

Copyright (C) 2011 Susan Bassnett.

All rights reserved. No part of this work may be reproduced in any form or by any means without permission in writing from the publisher.

The policy of Multilingual Matters/Channel View Publications is to use papers that are natural, renewable and recyclable products, made from wood grown in sustainable forests. In the manufacturing process of our books, and to further support our policy, preference is given to printers that have FSC and PEFC Chain of Custody certification. The FSC and/or PEFC logos will appear on those books where full certification has been granted to the printer concerned.

Typeset by Techset Composition Ltd, Salisbury, UK.

Printed and bound in Great Britain by the MPG Books Group. 